CZASOPISMO INŻYNIERII LĄDOWEJ, ŚRODOWISKA I ARCHITEKTURY JOURNAL OF CIVIL ENGINEERING, ENVIRONMENT AND ARCHITECTURE

JCEEA, t. XXXIII, z. 63 (4/16), październik-grudzień 2016, s. 193-200

Sławomir GUŁKOWSKI ${ }^{1}$

\title{
OTRZYMYWANIE CIENKICH WARSTW ABSORBERA CIGS METODA ROZPYLANIA MAGNETRONOWEGO DLA ZASTOSOWAŃ FOTOWOLTAICZNYCH
}

\begin{abstract}
W artykule przedstawiono metodę rozpylania magnetronowego w zastosowaniu do nanoszenia cienkich warstw krystalicznych absorbera CIGS stosowanych w cienkowarstwowych ogniwach słonecznych. Metoda rozpylania magnetronowego jest efektywną metodą produkcji cienkich warstw CIGS. Proces nanoszenia warstw można podzielić na dwie zasadnicze części: pierwsza to tworzenie prekursora CIG, tj. nanoszenie warstw metalicznych miedzi, galu i indu w odpowiednich proporcjach. Etap drugi to krystalizacja absorbera CIGS w wyniku procesu wygrzewania prekursora w obecności selenu. W artykule skupiono się na opracowaniu odpowiednich proporcji poszczególnych pierwiastków wchodzących w skład prekursora. Przebadano następujące konfiguracje nanoszenia poszczególnych warstw absorbera: $\mathrm{CuGa} / \mathrm{In}$ oraz $\mathrm{CuGa} / \mathrm{In} / \mathrm{Cu}$. Poszczególne warstwy naniesione zostały na podłoże molibdenowe, stanowiące tylny kontakt ogniwa budowanego na bazie absorbera CIGS. Warstwa molibdenu została przebadana metodą czteroostrzową w celu znalezienia zależności rezystywności od grubości warstwy. Przeprowadzono analizę składu pierwiastkowego warstwy za pomocą skaningowego mikroskopu elektronowego wyposażonego w system EDS. Dla każdej z otrzymanych warstw określono atomowe współczynniki proporcji występowania miedzi oraz galu w składzie warstwy. Na podstawie otrzymanych wyników badań dokonano optymalizacji parametrów technologicznych procesu takich jak: moc katody, ciśnienie oraz czas procesu, a także temperatura. Znaleziono zależności grubości warstw w funkcji czasu nanoszenia dla ustalonych warunków ciśnienia i mocy. Grubości poszczególnych warstw określono na podstawie badań profilometrycznych. W oparciu o opracowane parametry wykonane warstwy prekursora poddawane są obróbce termicznej w celu uzyskania absorbera CIGS.
\end{abstract}

Słowa kluczowe: fotowoltaika, ogniwa cienkowarstwowe, absorber CIGS, rozpylanie magnetronowe

\section{Wprowadzenie}

${ }^{1}$ Sławomir Gułkowski, Politechnika Lubelska, Wydział Inżynierii Środowiska, Instytut Inżynierii Odna-
wialnych Źródeł Energii, ul. Nadbystrzycka 38, 20-618 Lublin; tel. 81538 46 54; s.gulkowski@ pollub.pl 
Ogniwa słoneczne zbudowane na bazie diselenku miedziowo-indowo- galowego (ang. Cooper-Indium-Gallium-Diselenide - CIGS) stanowią obiecującą alternatywę dla ogniw wykonanych w oparciu o powszechnie wykorzystywane technologie krzemowe zarówno pod kątem ceny jak i sprawności. Wynika to z możliwości otrzymywania wysokiej jakości struktur półprzewodnikowych o grubości kilku mikrometrów na podłożach o dużej powierzchni i niskim koszcie, takich jak szkło sodowe czy stal nierdzewna. Dla porównania w krzemowym ogniwie krystalicznym grubość warstwy wynosi $300 \mu \mathrm{m}$. Ponadto znaczną część kosztów produkcji krzemowych ogniw słonecznych (65\%) pochłania etap przygotowania wysokiej jakości podłoża $\mathrm{Si}$, na który składają się procesy oczyszczania, krystalizacji a także cięcia, które prowadzą do strat materiału [1]. W przypadku ogniw heterozłączowych problem stanowi dopasowanie sieci krystalicznej [2]. Istotną przewagą cienkowarstwowych absorberów CIGS nad materiałami krzemowymi w zastosowaniach fotowoltaicznych jest również prosta przerwa energetyczna oraz wysoki współczynnik absorpcji, który umożliwia, przy grubościach warstwy rzędu kilku mikronów, absorpcję całości promieniowania padającego na ogniwo oraz jego konwersję na prąd elektryczny.

W ostatnich latach sprawność laboratoryjnych ogniw CIGS znacznie wzrosła i na chwilę obecną przekracza $22 \%$. Sprawność komercyjnych modułów wynosi ok. $15 \%$. Koszt produkcji szacuje się na $0.49 \$ / \mathrm{Wp}$, dla porównania koszt produkcji powszechnie używanych modułów krzemowych modułów krystalicznych wynosi $0.334 \$ / \mathrm{W}[3]$.

Wysokiej wydajności ogniwa słoneczne CIGS zbudowane są w oparciu o złącze p-n, na które składa się absorber diselenku miedziowo-indowogalowego typu p oraz siarczek kadmu typu n. Struktura złącza umieszczana jest najczęściej na podłożu ze szkła sodowego (SLG - Soda Lime Glass), na które nanoszona jest warstwa molibdenu stanowiąca kontakt dolny. W dalszej kolejności tworzone są warstwy przewodzące stanowiące kontakt górny ogniwa: $\mathrm{ZnO} / \mathrm{ZnO}-\mathrm{Al} / \mathrm{Al}$. Prowadzone są również prace badawcze nad wykorzystaniem warstwy $\mathrm{SnO}_{2}$ otrzymywanej metodą rozpylania magnetronowego [4].

Absorber CIGS jest kryształem o strukturze chalkopirytu w skład którego wchodzą cztery pierwiastki: miedź, ind, gal oraz selen. Utworzenie odpowiedniej struktury kryształu wymaga doboru właściwego składu atomowego wymienionych pierwiastków. Równania (1), (2) przedstawiają metodę obliczania składu atomowego miedzi i galu w strukturze absorbera.

$$
\begin{aligned}
& A R_{C u}=\frac{C u}{I n+G a} \\
& A R_{G a}=\frac{G a}{I n+G a}
\end{aligned}
$$


Wielkość współczynnika $A R_{C u}$ powinna mieścić się w przedziale $0.7 \div 1.0$. Natomiast w przypadku $A R_{G a}$ ilość Ga nie powinna przekraczać 0.3 . Skład atomowy selenu w strukturze absorbera to ok. $50 \%$.

$\mathrm{W}$ artykule przedstawiono metodę rozpylania magnetronowego jako technikę osadzania cienkich warstw z powierzchni elektrody rozpylanej (targetu). Dokonano optymalizacji parametrów technologicznych procesu nanoszenia warstw pod kątem składu pierwiastkowego absorbera.

\section{Opis procedury badawczej}

Do nanoszenia warstw metalicznych wykorzystany został magnetron firmy Alliance Concept Line 450, przedstawiony na rysunku 1. Uwzględniając możliwość pracy urządzenia zarówno w trybie DC (Direct Current) jak i RF (Radio Frequency) system umożliwia nanoszenie zarówno materiałów przewodzących jak i nieprzewodzących na podłoże w kształcie koła o średnicy równej średnicy tarczy katody. Przykładowe katody (targety) pokazane zostały na rysunku 2. Średnica katody wynosi 4 cale.

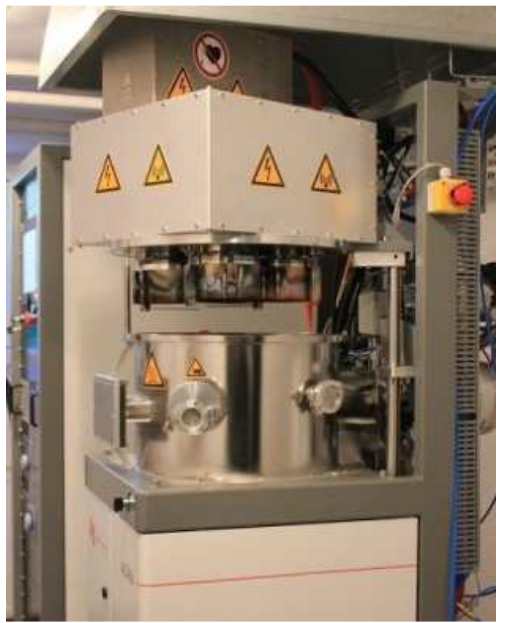

Rys. 1. Magnetron firmy Alliance Concept 450

Fig. 1. Alliance Concept Sputtering Magnetron System Line 450

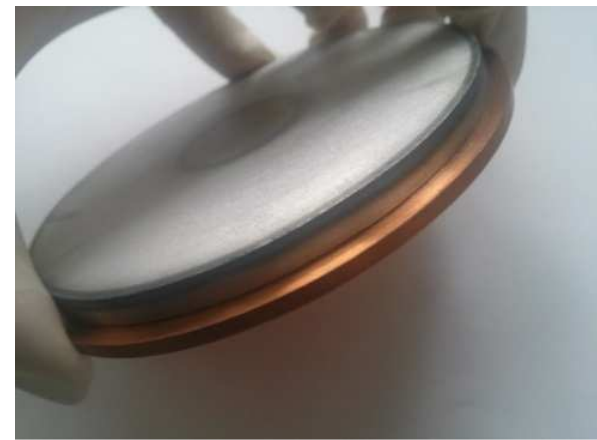

Rys. 2. Tarcza katody (target)

Fig. 2. Sputtering target

Urządzenie wyposażone jest w turbo pompę, umożliwiającą odpompowanie komory do ciśnienia $p_{0}=10^{-5} \mathrm{mbar}$ na początku procesu, oraz utrzymanie określonego poziomu próżni podczas procesu. Gazem roboczym we wszystkich przeprowadzonych eksperymentach był Argon. 


\subsection{Przygotowanie podłoży}

Badania eksperymentalne przeprowadzono na podłożach szklanych o rozmiarach $2.5 \mathrm{~cm} \times 7.5 \mathrm{~cm}$ ze szkła sodowego ( $\mathrm{SLG}-$ Soda Lime Glass), które przed procesem nanoszenia poddane zostały czyszczeniu chemicznemu w myjce ultradźwiękowej w acetonie, alkoholu etylowym a następnie wysuszone strumieniem gazu $\mathrm{N}_{2}$.

W pierwszej kolejności naniesiona została warstwa molibdenu. Parametry technologiczne procesu dobrane zostały zgodnie $\mathrm{z}$ wykonaną charakterystyką szybkości depozycji Mo dla zadanych warunków, tj. moc $P=80 \mathrm{~W}$, przepływ argonu $-20 \mathrm{sccm}$, ciśnienie $p=2.0 \cdot 10^{-2} \mathrm{mbar}$, czas trwania procesu $t=60 \mathrm{~min}$ oraz temperatura w komorze $T=25^{\circ} \mathrm{C}$. Otrzymane warstwy przebadane zostały pod kątem przewodnictwa elektrycznego.

\subsection{Magnetronowe osadzanie składników absorbera}

Osadzanie składników absorbera dokonano z wykorzystaniem tarczy katodowych (targetów) o czystości nie mniejszej niż 99.99\%. Z uwagi na bardzo niską temperaturę topnienia galu, nie jest praktykowana produkcja katod z tego materiału. Umieszczenia galu w strukturze absorbera dokonano z wykorzystaniem targetu CuGa. Pozostałe katody to czyste tarcze indu (In) i miedzi $(\mathrm{Cu})$. W celu określenia optymalnych warunków procesu nanoszenia składników absorbera przeprowadzono serię eksperymentów, w których określono czasy trwania procesu nanoszenia poszczególnych warstw materiału targetu dla niezmiennych pozostałych parametrów technologicznych procesu tj. mocy, ciśnienia czy temperatury. Na podstawie badań EDS określono atomowe składy pierwiastkowe opisane równaniami (1) i (2) w funkcji współczynników, zdefiniowanych jako stosunek grubości poszczególnych warstw, tj. $\mathrm{CuGa} / \mathrm{In}$ oraz $\mathrm{Cu} / \mathrm{In}$. Szczegółowy plan przeprowadzonych eksperymentów przedstawiony został w tabelach $1-3$. Dla wszystkich trzech materiałów katody zastosowano następujące, stałe, parametry procesu rozpylania: moc $P=80 \mathrm{~W}$, przepływ argonu 20sccm, ciśnienie $p=2.0 \cdot 10^{-2} \mathrm{mbar}$, oraz temperatura w komorze $T=25^{\circ} \mathrm{C}$. Grubości warstw określono w oparciu o czasy depozycji zgodnie z wykresami charakterystyk zamieszczonymi w niniejszej oraz we wcześniejszej pracy [5].

W tabeli 1 przedstawiono grubości kolejnych warstw nanoszonych w jednym cyklu, jedna warstwa po drugiej, w następującej kolejności: $\mathrm{CuGa/In.} \mathrm{Przy-}$ jęto stałą wartość grubości dla warstwy CuGa oraz zmienną dla warstwy In. Analiza EDS pozwala wyznaczyć zależność składu pierwiastkowego tak przygotowanej struktury. W celu zwiększenia dokładności analizy EDS zmodyfikowano program nanoszenia warstw w taki sposób, aby całkowita grubość warstwy absorbera (a właściwie prekursora) została osiągnięta poprzez cykliczne nanoszenie kolejnych warstw w następującej kolejności (4 cykle): $\mathrm{CuGa} / \mathrm{In} / \mathrm{CuGa} / \mathrm{In}$ Parametry zastosowane w tej części eksperymentu przedstawia tabela 2. 
Tabela 1. Parametry warstw $\mathrm{CuGa}$, In nanoszonych w jednym cyklu eksperymentalnym

Table 1. Parameters of the $\mathrm{CuGa}$, In layers deposited in one experimental cycle

\begin{tabular}{|c|c|c|c|c|}
\hline Nr próbki & Cykle & $\begin{array}{c}\text { Grubość } \\
\text { CuGa }[\mathbf{n m}]\end{array}$ & $\begin{array}{c}\text { Grubość } \\
\text { In [nm] }\end{array}$ & CuGa/In \\
\hline 1 & 1 & 200 & 500 & 0.4 \\
\hline 2 & 1 & 200 & 400 & 0.5 \\
\hline 3 & 1 & 200 & 300 & 0.7 \\
\hline 4 & 1 & 200 & 200 & 1.0 \\
\hline
\end{tabular}

Tabela 2. Parametry warstw $\mathrm{CuGa}$, In nanoszonych w czterech cyklach eksperymentalnych Table 2. Parameters of the $\mathrm{CuGa}$, In layers deposited in four experimental cycles

\begin{tabular}{|c|c|c|c|c|}
\hline Nr próbki & Cykle & $\begin{array}{c}\text { Grubość } \\
\text { CuGa [nm] }\end{array}$ & $\begin{array}{c}\text { Grubość } \\
\text { In [nm] }\end{array}$ & CuGa/In \\
\hline 5 & 4 & 70 & 95 & 0.74 \\
\hline 6 & 4 & 60 & 105 & 0.57 \\
\hline 7 & 4 & 50 & 145 & 0.35 \\
\hline
\end{tabular}

Eksperymenty przeprowadzone $\mathrm{w}$ oparciu o parametry przedstawione w tabelach 1 i 2 umożliwiają optymalizację składu pierwiastkowego pod kątem występowania galu w strukturze warstwy. Kolejna seria eksperymentów dotyczy nanoszenia warstw miedzi przy ustalonym współczynniku $\mathrm{CuGa} / \mathrm{In}$ w celu optymalizacji składu pierwiastkowego pod kątem jej występowania w strukturze warstwy. Tabela 3 przedstawia grubości poszczególnych warstw osadzanych cyklicznie wg schematu $\mathrm{CuGa} / \mathrm{In} / \mathrm{Cu} / \mathrm{CuGa} / \mathrm{In} / \mathrm{Cu}$.

Tabela 3. Parametry warstw $\mathrm{CuGa}$, In, Cu nanoszonych w czterech cyklach eksperymentalnych Table 3. Parameters of the $\mathrm{CuGa}$, $\mathrm{In}, \mathrm{Cu}$ layers deposited in four experimental cycles

\begin{tabular}{|c|c|c|c|c|c|c|}
\hline Nr próbki & Cykle & $\begin{array}{c}\text { Grubość } \\
\text { CuGa [nm] }\end{array}$ & $\begin{array}{c}\text { Grubość } \\
\text { In [nm] }\end{array}$ & $\begin{array}{c}\text { Grubość } \\
\text { Cu [nm] }\end{array}$ & $\mathbf{C u G a / I n ~}$ & Cu/In \\
\hline 8 & 4 & 50 & 145 & 10 & 0.3 & 0.1 \\
\hline 9 & 4 & 50 & 145 & 25 & 0.3 & 0.2 \\
\hline 10 & 4 & 50 & 145 & 60 & 0.3 & 0.4 \\
\hline
\end{tabular}

\subsection{Analiza spektralna składu pierwiastkowego warstwy}

Wszystkie podłoża zostały zbadane pod kątem analizy pierwiastkowej metodą EDS. Wykorzystano do tego celu skaningowy mikroskop elektronowy Hitachi SU 3500. Zastosowano napięcie przyspieszające 20kV. Obserwacji mikroskopowej dokonano dla odległości roboczej (working distance) wynoszącej $10 \mathrm{~mm}$. 


\section{Wyniki badań $\mathrm{i}$ ich analiza}

Otrzymane metodą rozpylania magnetronowego warstwy molibdenu jak i warstwy stanowiące składniki absorbera CIGS przebadane zostały odpowiednio pod kątem rezystywności jak i składu pierwiastkowego. Rysunek 3 przedstawia wykres zależności grubości warstwy Mo w funkcji czasu dla zadanych, wymienionych wcześniej parametrów technologicznych procesu. Rysunek 4 przedstawia wykresy zależności oporu w funkcji grubości warstwy.

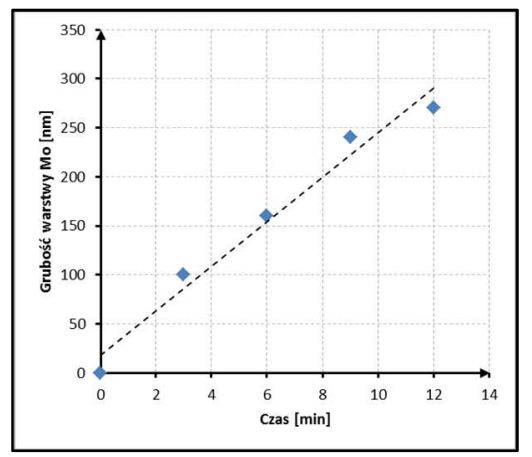

Rys. 3. Grubość warstwy molibdenu w funkcji czasu depozycji

Fig. 3. Thickness of the molibdenium layer in the function of deposition time

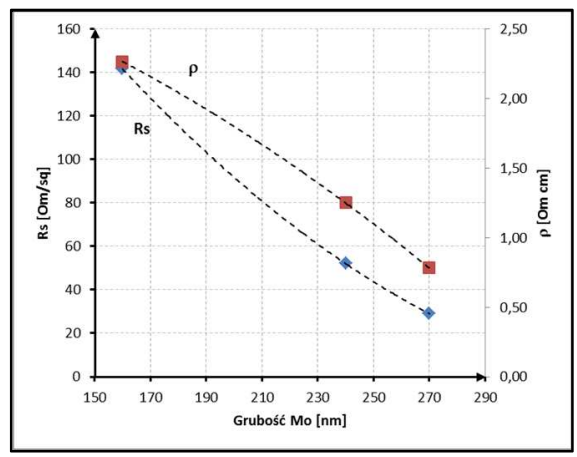

Rys. 4. Zależności oporu warstwy molibdenu w funkcji grubości warstwy

Fig. 4. Dependence of the sheet resistant and resistivity on the Mo layer thickness

W oparciu o powyższe wykresy określono czas nanoszenia warstwy Mo, dla

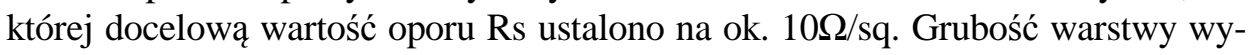
niosła ok $1 \mu \mathrm{m}$. Na tak przygotowane podłoże naniesiono warstwy $\mathrm{CuGa}$ oraz In zgodnie z parametrami przedstawionymi w tabelach 1 i 2 . Rysunek 5 przedstawia wyniki badań EDS warstw otrzymanych w jednym cyklu (tabela1), rysunek 6 natomiast wyniki badań EDS struktury otrzymanej w czterech cyklach (tabela 2).

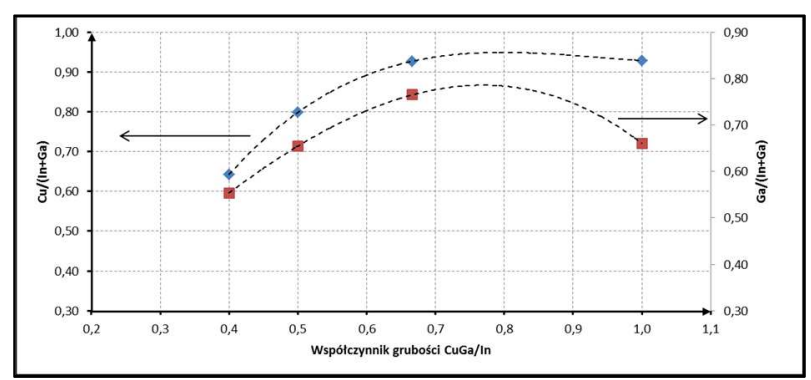

Rys. 5. Zawartość miedzi i galu w strukturze warstwy w funkcji współczynnika grubości $\mathrm{CuGa} / \mathrm{In}$ warstw

Fig. 5. Amount of copper and gallium in the layer's structure in the function of $\mathrm{CuGa} / \mathrm{In}$ thickness ratio 
Wyniki pomiarów z rysunku 5 jednoznacznie wskazują zawyżoną zawartość galu w strukturze warstwy. Ponadto, porównując rezultaty przedstawione na rysunkach 5 i 6 należy stwierdzić, że sposób nanoszenia warstw ma istotne znaczenie dla rejestrowanych sygnałów EDS. Stąd wybór sekwencyjnej metody osadzania. Z wykresu przedstawionego na rysunku 6 wynika, że wartość $A r_{G a}$ jest mniejsza niż 0.3 dla współczynnika grubości $\mathrm{CuGa/In} \mathrm{nie} \mathrm{większego} \mathrm{niż} \mathrm{0.4.}$ Jednakże przy tej wielkości współczynnika zawartość miedzi rzędu 0.3 jest niewystarczająca. $\mathrm{Z}$ tego powodu dodano do procesu etap nanoszenia warstwy $\mathrm{Cu}$ zgodnie z parametrami opisanymi w tabeli 3 .

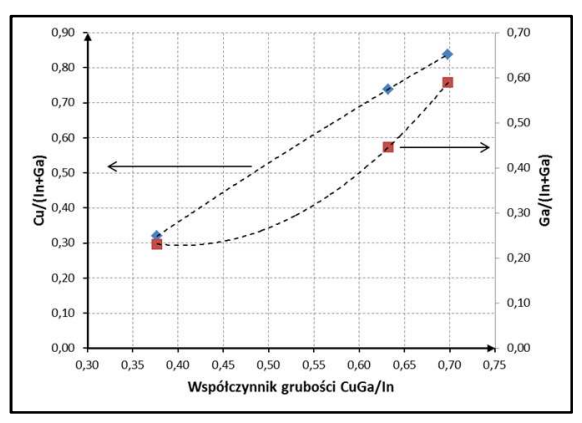

Rys. 6. Zależność koncentracji pierwiastków dla warstw otrzymanych w czterech cyklach eksperymentalnych

Fig. 6. Dependence of composition of the layers obtained in four experimental cycles

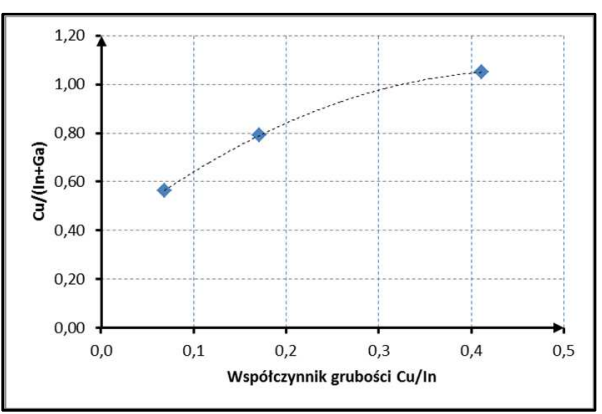

Rys. 7. Zależność koncentracji $\mathrm{Cu}$ w strukturze warstwy w funkcji współczynnika grubości $\mathrm{Cu} / \mathrm{In}$

Fig. 7. Dependence of $\mathrm{Cu}$ concentration in the layer on $\mathrm{Cu} / \mathrm{In}$ thickness ratio

Rezultaty badań EDS warstw $\mathrm{CuGa} / \mathrm{In} / \mathrm{Cu}$ przedstawiono na rysunku 7. $\mathrm{Z}$ wykresu wynika, że parametr $A R_{C u}$ osiąga wymaganą wartość opisaną zależnością (1) w przypadku współczynnika grubości $\mathrm{Cu} / \mathrm{In}$ mieszczącego się w przedziale od 0.2 do 0.4 .

\section{Wnioski}

Z przedstawionych rezultatów badań wynika, że stosując metodę sekwencyjnego osadzania warstw techniką rozpylania magnetronowego z materiałów $\mathrm{CuGa}, \mathrm{In}, \mathrm{Cu}$ przy założeniu określonych grubości kolejnych warstw możliwe jest uzyskanie właściwego składu pierwiastkowego poszczególnych materiałów wchodzących w skład absorbera ogniw zbudowanych na bazie diselenku miedziowo-indowo-galowego. Stosunek grubości warstw $\mathrm{CuGa} / \mathrm{In}$ nie powinien przekraczać 0.4 dla zachowania odpowiedniej koncentracji galu w strukturze absorbera. W przypadku warstwy miedzi stosunek grubości Cu/In przy zachowaniu stałej wartości $\mathrm{CuGa} / \mathrm{In}$ powinien zawierać się w przedziale między 0.2 a 0.4. Utworzona struktura po poddaniu procesowi wygrzewania w temperaturze $600^{\circ} \mathrm{C}$ w obecności selenu powoduje powstanie absorbera CIGS. 


\section{Literatura}

[1] Hegedus S., Luque A.: Handbook of Photovoltaic Science and Engineering. John Wiley \& Sons Ltd, Chicheser, 2003.

[2] Zdyb A., Olchowik, Mucha M.: The Dependence of GsAs and Si Surface Energy on Crystal Planes Misorientation Angle, Materials Science Poland, 24, No 4 (2006) 1109-1114.

[3] Horowitz H. Fu R. Woodhouse M. An analysis of glass-glass CIGS manufacturing costs. Solar Energy Materials and Solar Cells, vol. 154, 2016, p. 1-10.

[4] Grudniewski T., Lubańska Z., Czernik S.: Charakterystyka AFM cienkich warstw $\mathrm{SnO}_{2}$ uzyskanych podczas sputteringu magnetronowego przy wybranych warunkach procesu. Czasopismo Inżynierii Lądowej, Srodowiska i Architektury - Journal of Civil Engineering, Environment and Architecture, JCEEA, t. XXXII, z. 62 (2/15), 2015, s. 99-106, DOI:10.7862/rb.2015.40.

[5] Gulkowski S., Krawczak E., Olchowik J.M.: Optimization of Metallic Precursor Thickness Ratio for CIGS Solar Cell Prepared by Magnetron Sputtering Process. Procedings of the $31^{\text {st }}$ EU PVSEC, Hamburg, 2015, p. 1330-1332.

\section{PREPARATION OF THIN LAYER CIGS ABSORBER BY MAGNETRON SPUTTERING TECHNIQUE FOR PHOTOVOLTAIC APPLICATIONS}

\section{S u m m a r y}

This paper presents the sputtering magnetron system technology used to thin crystalline absorber deposition as a basic structure of CIGS solar cells. Magnetron sputtering is an effective method of thin CIGS layers production. Deposition process can be divided into two steps: first one is the precursor deposition which consist of deposition process of metallic layers with appropriate composition. Second step consist of crystallization process of CIGS absorber by heating precursor sample in high temperature in selenium ambient. This paper focuses on composition of the precursor structure. Following configuration of the layer structure has been investigated: $\mathrm{CuGa} / \mathrm{In}$ and $\mathrm{CuGa} / \mathrm{In} / \mathrm{Cu}$. As a substrate soda lime glass (SLG) covered by thin molybdenum layer deposited with use of sputtering magnetron system was chosen. Back contact Mo layer has been analyzed with use of four point probe in order to find dependence of the sheet resistance on thickness of the layer. With use of scanning electron microscopy with electron dispersive spectroscopy (EDS) system chemical characterization of the layers has been done. For each layer ratios of $\mathrm{Cu} /(\mathrm{In}+\mathrm{Ga})$ and $\mathrm{Ga} /(\mathrm{In}+\mathrm{Ga})$ have been calculated. On the basis of measurement results optimization of the technological parameters of the process like cathode power, pressure, temperature and deposition time was done. Dependence of the thickness of the layer in the function of deposition time for a given gas pressure and power has been found. In order to obtain CIGS absorber annealing process of precursor layer is demanded.

Keywords: photovoltaics, thin film solar cells, CIGS absorber, magnetron sputtering

DOI: $10.7862 / \mathrm{rb} .2016 .263$

Przestano do redakcji: $30.06 .2016 \mathrm{r}$.

Przyjęto do druku: 20.12.2016 r. 